\title{
The Australian Contribution to the History of the Pneumoconioses
}

Cowen, B. S., 'Tuberculosis in a mining community', Intercol. Med. J. Australasia, 1902, 7, 432.

Cumpston, A., 'Health and disease in the Broken Hill mining industry', in Broken Hill Mines, ed. M. Radmanovitch and J. T. Woodcock, Melbourne, 1968, p. 537.

Cumpston, J. H. L., 'Tuberculosis in Australia', Med. J. Aust., 1931, 2, 153.

Cumpston, J. H. L., 'Statistical review of tuberculosis in Australia', Trans. Aust. med. Congr. (B.M.A.), 1923, First Session, p. 237.

Fletcher, C. M., 'Pneumoconiosis of coal miners', Br. med. J., 1948, i, 1015 and 1065.

George, W. E., 'The pneumoconiosis of New South Wales coal workers', in Coal in Australia, Melbourne, Australasian Institute of Mining and Metallurgy, 1953, p. 320.

Grorge, W. W. and Wallman, L. S., A Medical Examination of Employees of the Coal Mining Industry of New South Wales, Sydney, Joint Coal Board, 1949.

Gisson, J. C. and Hugh-Jones, P., Lung Function in Coalworkers' Pneumoconiosis, M.R.C. Spec. Rep. Ser. No. 290, London, H.M.S.O., 1955.

Holmes, M. J., 'Tuberculosis in Australia', Med. J. Aust., 1937, $2,813$.

Holster, A., Exhibition of Contributions to the Literature on Pneumoconiosis by Australian Authors: Catalogue, Sydney, Royal Australasian College of Physicians, 1970.

HunTER, D., The Diseases of Occupations, London, English University Press, 1955, p. 891 et seq.

Joint Coal Board: Pneumoconiosis Statistics 1962: New South Wales Coal Industry, Sydney, 1962.

MCKenzIe, H. I., GuICK, M. and OUTHRED, K. S., 'Chronic bronchitis in coal miners: ante-mortem/post-mortem comparisons', Thorax, 1969, $24,527$.

MeIKLlejohn, A., 'History of lung diseases of coal miners in Great Britain; Part II, 18751920', Br. J. indus. Med., 1952, 9, 93; 'Part III, 1920-1952', 1952, 9, 208.

MOORE, K. R., 'Silicosis in Australia', in Records of the International Silicosis Conference, Geneva 1930, Geneva, International Labour Office, 1930.

Nelson, W. T., Report on an Investigation of the Pulmonary Condition of Mine Employees, Western Australia . . 1925-26, Service Publication No. 5, Division of Industrial Hygiene, Commonwealth Department of Health, Canberra, 1926.

Orenstein, A. J., 'The history of pneumoconiosis: A brief review', Sth Afr. med. J., 1957, 31, 797.

OUTHRED, K., 'Chronic Obstructive Lung Disease in New South Wales Coal Miners', roneoed typescript, 1967.

Summons, W., Miner's Phthisis: Reports of an Investigation at Bendigo into the Prevalence, Nature, Causes and Prevention of Miners' Phthisis, and the Ventilation of the Bendigo Mines, Melbourne, Stillwell, 1907. (These two are usually seen bound together with the above title, but they were probably originally issued separately in 1907 and 1906 respectively.)

Thomas, B. and GandeviA, B., 'Dr. Francis Workman, emigrant, and the history of taking the cure for consumption in the Australian Colonies', Med. J. Aust., 1959, $1,1$.

\section{ADDENDUM}

This paper is based on a paper read at a symposium held in the Department of Medical History, University of Melbourne, 21-23 May 1970. Since it was written, some additional references prior to 1900 to respiratory problems in miners have been identified and the bibliography extended. For some discussion of this material, see B. Gandevia 'Occupation and disease in Australia since 1788', Bull. Post-Grad. Cttee Med., Univ. Syd., 1971, 27, 157 and 199, and especially 200-201 and related notes and references. 